\title{
Candi Sojiwan Dalam Pemugaran
}

\section{Masyhudi}

Keywords: restoration, conservation, temple, protection, heritage

\section{How to Cite:}

Masyhudi, nfn. (2005). Candi Sojiwan Dalam Pemugaran. Berkala Arkeologi, 25(1), 110-118. https://doi.org/10.30883/jba.v25i1.915

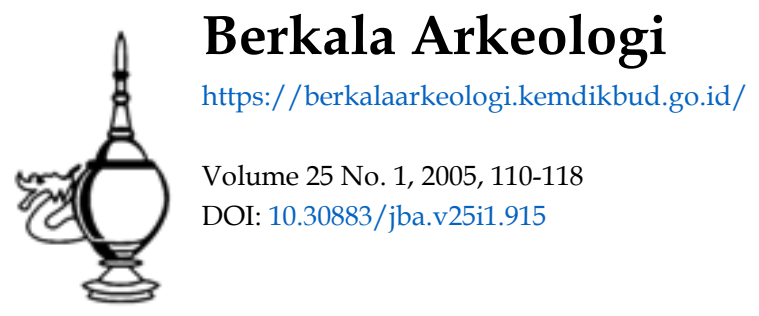

\section{(c) (i) (3)}

This work is licensed under a Creative Commons Attribution-NonCommercial-ShareAlike 4.0 International License. 


\title{
CANDI SOJIWAN DALAM PEMUGARAN
}

\author{
Oleh Masyhudi
}

\section{Pendahuluan}

Sebagaimana telah ditegaskan oleh Soekmono dalam disertasinya yang berjudul Candi Fungsi dan Pengertiannya, candi adalah bangunan suci tempat pemujaan dewa. Candi melambangkan mahameru, yaitu gunung yang menjadi pusat alam semesta. Bangunan candi yang biasanya terdiri atas tiga bagian, yaitu kaki, tubuh, dan atap melambangkan tiga dunia, yaitu bhurloka, bhuwarloka, dan swarloka (Stutterheim, 1937: 245; Boechari, 1978: 13).

Disebutkan dalam kitab Mânasâra-Çilpaçastra -- kitab yang berisi aturan-aturan pembangunan kuil di India -- bahwa sebelum suatu bangunan kuil didirikan maka arsitek pendeta (sthapaka) dan arsitek perencana (sthapati) harus lebih dahulu menilai kondisi dan kemampuan lahan yang akan dijadikan tempat berdirinya bangunan suci tersebut (Acharya, 1993: 13-21; Kramrisch, 1946: 3-17; Mundardjito, 1993: 13). Kitab tersebut juga menerangkan bahwa lahan tempat berdirinya suatu bangunan kuil dinilai sangat tinggi, bahkan lebih penting dari bangunan suci itu sendiri (Mundardjito, 1993: 239).

Peninggalan sejarah dan purbakala merupakan bukti otentik sebagai bentuk nyata yang menyimpan makna dan nilai-nilai luhur. Kini, sebagai bangsa yang sedang membangun memerlukan hal tersebut sebagai sumber inspirasi untuk bertindak ke depan mencapai cita-cita bangsa. Oleh karenanya perlu upayaupaya pelestarian dan pemanfaatan terhadap peninggalan sejarah dan purbakala tersebut agar dapat diwariskan kepada generasi yang akan datang. Suatu peningglan yang telah

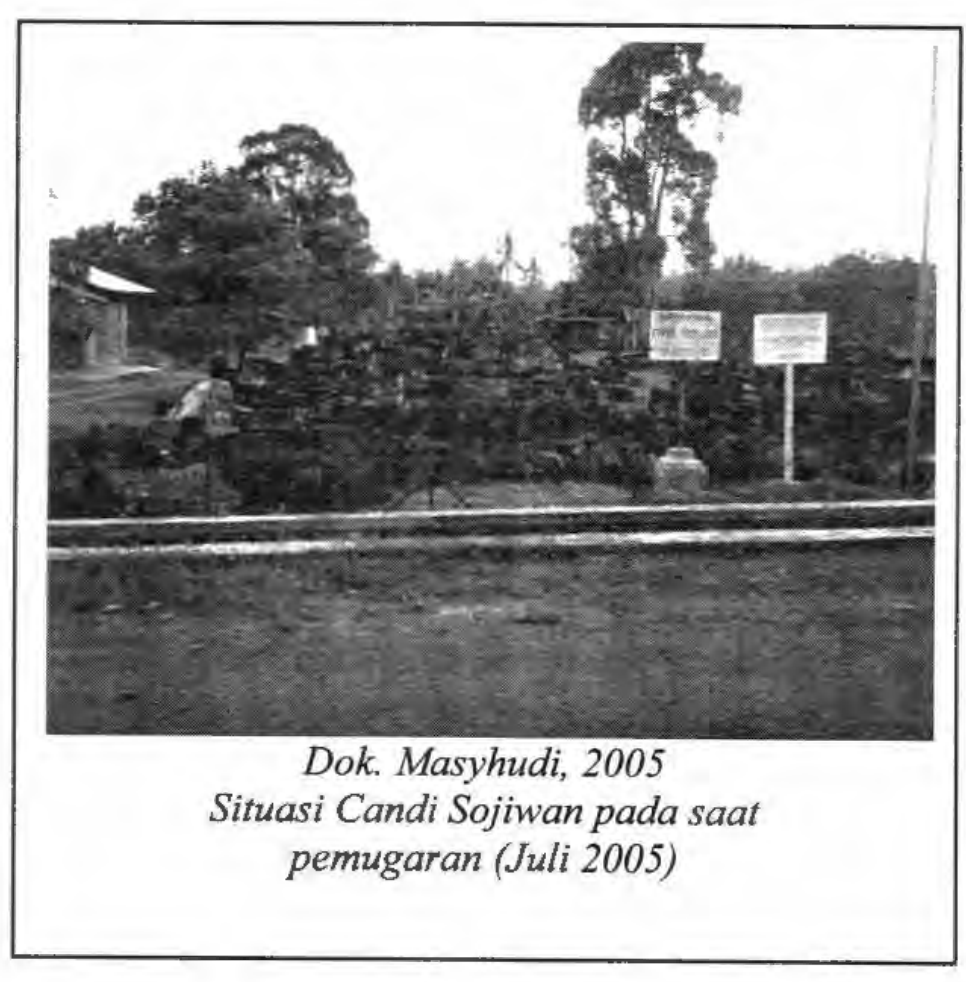


dipugar sesuai dengan bentuk aslinya, berarti kelestarian dapat dipertahankan dan hal tersebut akan banyak memberikan manfaat kepada pendidikan, ilmu pengetahuan, sumber sejarah, sosial budaya, sosial ekonomi dan lain sebagainya. Dalam rangka itu juga, Candi Sojiwan yang terletak di Desa Sojiwan, Kecamatan Prambanan, Kabupaten Klaten, Jawa Tengah sedang dilakukan pemugaran.

Secara umum, pemugaran Candi Sojiwan tersebut dimaksudkan sebagai upaya melestarikan, menyelamatkan, memelihara serta mengamankan situs bangunan kepurbakalaan, sebagai warisan budaya nasional, melestarikan nilai-nilai budaya bangsa yang terkandung pada peninggalan sejarah dan purbakala, agar dapat dijadikan sarana pendidikan, dan pembinaan kepribadian bangsa. Pemugaran suatu bangunan peninggalan sejarah dan purbakala, baik yang menyangkut kegiatan-kegiatan prapemugaran maupun pelaksanaan pemugaran secara intensif antara lain diperoleh dari studi kelayakan, laporan hasil kegiatan-kegiatan teknis, dan kegiatan-kegiatan penelitian lain.

Candi Sojiwan didirikan sekitar pertengahan abad IX Masehi. Susunan dan gaya arca yang ditemukan di Candi Sojiwan dapat dihubungkan dengan Candi Plaosan (Kempers, $1959: 62$ ). Di depan singgasana, di tengah-tengah lantai bilik candi tersebut terdapat perigi (lubang) dan di dalam perigi ditemukan beberapa lempengan emas tipis bergambar kura-kura dan naga serta beberapa potong tulang yang telah hangus (Blom, 1935 : 109-110). Akan tetapi, pendapat tersebut dibantah oleh Soekmono, bahwa lubang yang terdapat di tengah lantai sangat dangkal sehingga tidak mungkin terdapat kepingan emas dan potongan tulang, dan seperti pada umumnya bangunan candi yang berlatar belakang agama Budha tidak pernah ditemukan adanya perigi pada lantainya, namun di dalam bilik candi biasanya terdapat singgasana (Soekmono, $1977: 47-48$ ).

Candi Sojiwan yang kini tinggal bagian kakinya berorientasi ke barat, hal ini tampak pada bagian kaki candi di sebelah barat terdapat tangga yang diperkirakan mengarah ke pintu masuk ke dalam candi. Di sekitar bangunan candi terdapat reruntuhan batu candi dan sebagian telah disusun sebagai susunan percobaan, karena pada saat pengamatan berlangsung bangunan Candi Sojiwan tersebut sedang dipugar.

Pemugaran Candi Sojiwan dimaksudkan sebagai upaya melestarikan, menyelamatkan, memelihara serta mengamankan situs bangunan kepurbakalaan, sebagai warisan budaya nasional, melestarikan nilai-nilai budaya bangsa yang terkandung pada peninggalan sejarah dan purbakala, agar dapat dijadikan sarana pendidikan, dan pembinaan kepribadian bangsa.

Pemugaran suatu bangunan peningglan sejarah dan purbakala, baik yang menyangkut kegiatan-kegiatan prapemugaran maupun pelaksanaan pemugaran 
secara intensif antara lain diperoleh dari studi kelayakan, laporan hasil kegiatankegiatan teknis, dan kegiatan-kegiatan penelitian lain.

\section{Pra-Pemugaran (Persiapan)}

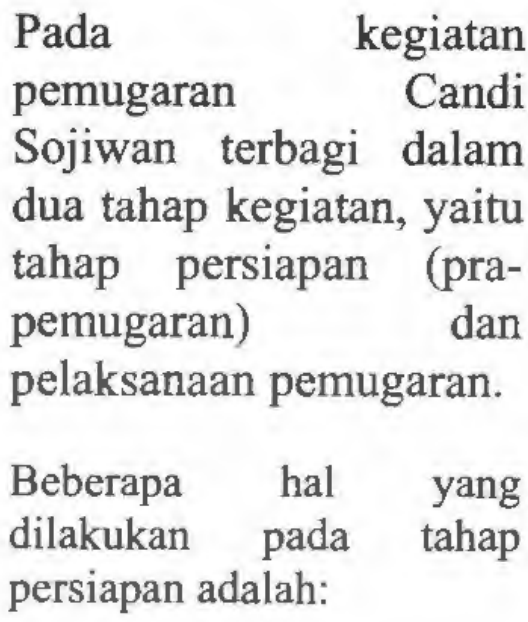

\section{A. Tekno Arkeologi}

Dalam pemugaran Candi Sojiwan, Tekno arkeologi yang dimaksudkan adalah

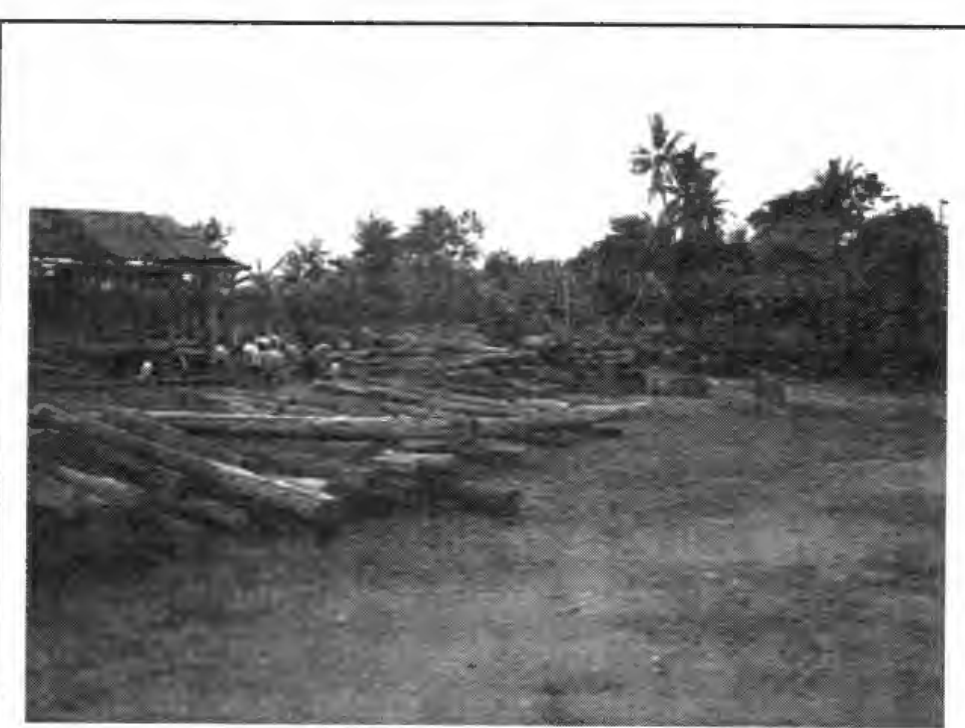

Dok. Masyhudi 2005

Material (sarana pemugaran Candi Sojiwan) bidang yang bertugas melaksanakan pengukuran, penggambaran, dan konstruksi. Dari pelaksanaan tugas tersebut akan diperoleh hasil analisis studi lapangan berupa perhitungan teknis untuk persiapan sarana dan prasarana yang digunakan dalam pemugaran Candi Sojiwan. Hal ini juga dilakukan dalam beberapa tahapan, yaitu :

1. Pengukuran

Pengukuran terhadap candi ini dilaksanakan dengan maksud untuk memperoleh data yang akurat mengenai letak bangunan, pergeseran, kemelesakan bangunan candi dan pembongkaran sisa bangunan.

2. Penelitian tanah

Dalam kegiatan penyusunan rencana pemugaran terlebih dahulu dilakukan penelitian terhadap pondasi bangunan candi dan lapisan tanah di bawah bangunan candi yang akan dipugar.

3. Teknik konstruksi

Dari aspek teknik konstruksi, terjadinya kemelesakan dan pergeseran candi menarik untuk dibicarakan, terutama faktor-faktor penyebabnya, 
sedangkan hal lain adalah faktor penyebab keruntuhan bagian atap bangunan.

4. Susunan Percobaan

Sebelum dilakukan penyusunan batubatu candi ke tempatnya semula, terlebih dahulu dilakukan penyusunan percobaan, dimaksudkan untuk memastikan batubatu yang akan dipasang untuk rekonstruksi bangunan candi.

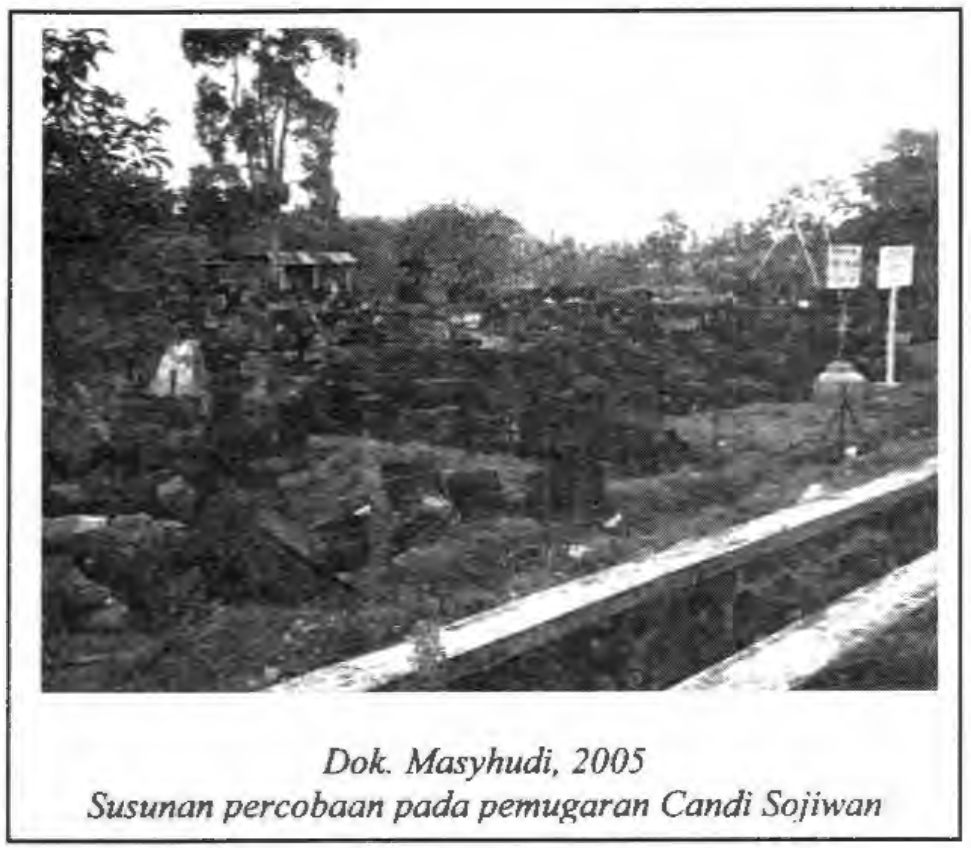

\section{Perencanaan}

Setelah dilakukan penelitian teknis, baik sebelum dibongkar maupun selama pembongkaran dapat diketahui bahwa kedudukan pondasi tubuh Candi Sojiwan dalam kondisi masih baik, meskipun pondasi pada tangga mengalami kemelesakan. Kemelesakan itu perlu adanya pengangkatan dalam pemasangan kembali serta perapatan terhadap nat-nat batu sesuai dengan rencana rekonstruksinya

\section{B. Konservasi}

Dalam pemugaran, pekerjaan pokok dalam konservasi adalah pengawetan bahan bangunan. Keterlibatan konservasi dalam pemugaran Candi Sojiwan adalah mengidentifikasi jenis bangunan, kuantitas dan kualitas bangunan sebelum dilakukan pembongkaran. Batu-batu candi, baik batu kulit maupun batu isian berasal dari bahan andesit. Batu-batu tersebut juga telah mengalami kerusakan yang disebabkan olek faktor teknis, organik, phisik, dan iklim.

\section{Dokumentasi}

Tugas pokok dokumentasi dalam pemugaran adalah membuat dokumen berupa rekaman dalam bentuk visual terhada obyek (Candi Sojiwan), yaitu merekam sejak persiapan pembongkaran sampai dengan pemasangan kembali yang meliputi foto situasi sebelum dipugar, foto detail setiap bidang, dan foto selama pembongkaran. 


\section{Pelaksanaan Pemugaran}

Beberapa hal yang dilakukan pada tahap pelaksanaan pemugaran adalah sama halnya dengan langkah-langkan pada tahap persiapan (pra pemugaran), yaitu sebagai wujud dari perencanaan yang telah disiapkan pada tahap persiapan. Langkah-langkah tersebut adalah sebagai berikut.

\section{A. Tekno Arkeologi}

Pada saat tulisan ini dibuat pelaksanaan pemugaran masih dalam proses awal, yaitu baru sampai tahap pemasangan pondasi atau bagian kaki candi. Kegiatan ini dilakukan setelah dilakukan pemasangan landasan dan setelah ditentukan ketinggian batu pondasi lapis 1, baru kemudian dilakukan pemasangan kembali batu candi. Prinsip dasar yang dipakai dalam pemasangan batu-batu candi tersebut dipasang satu lapis dan dipasang secara tetap (permanen), setelah ada kepastian kesesuaian lapis batu dengan lapis batu di bawah dan di atasnya. Oleh karenanya setiap pemasangan satu lapis batu terlebih dahulu dilakukaan penyusunan percobaan pada posisi masing-masing batu. Susunan percobaan ini disesuaikan dengan rencana pemasangan kembali baik dalam hal pengakatan maupun perapatan terhadap nat-nat batu serta titik-titik sudutnya sesuai dengan koordinat yang sudah direncanakan. Apabila susunan percobaan ini telah sesuai dengan rencana semula yaitu sesuai dengan posisi batu di atas dan di bawahnya, kemudian batu susunan percobaan tersebut dibongkar kembali, yaitu setelah memindahkan titik sudut ke alat bantu yang terbuat dari kayu yang disebut bhowplank. Baru kemudian batu-batu tersebut dipasang kembali secara permanen.

Karena pelaksanaan pemugaran ini dalam tahap awal, maka tahapan yang ada secara keseluruhan diharapkan akan sesuai dengan rencana-rencana yang telah ditentukan pada tahap persiapan (pra-pemugaran). Beberapa tahap yang belum terlaksana meliputi pemasangan lantai selasar, pemasangan tubuh dan atap candi. Dalam pemasangan lantai selasar terdapat kesulitan-kesulitan yang pada prinsipnya sama dengan pemasangan bagian pondasi dan kaki candi karena susunan lantai selasar akan menentukan keletakan bagian tubuh dan atap candi di atasnya, baik secara horisontal maupun secara vertikal. Demikian halnya untuk pemasangan tubuh dan atap candi serta pemasangan tangga candi.

Dalam pemugaran Candi Sojiwan perlu dikemukakan bahwa batu-batu candi yang asli dan yang belum ditemukan pada saat pelaksanaan pemugaran akan diganti dengan batu baru. Penggantian tersebut dilakukan atas dasar pertimbangan kesesuaian warna dan kualitas batu, kemudian batu 
tersebut diberi tanda dengan timah hitam yang dipasang di tengah-tengah permukaan batu, dengan cara memasukkan timah hitam ke dalam lubang hasil pengeboran di permukaan batu.

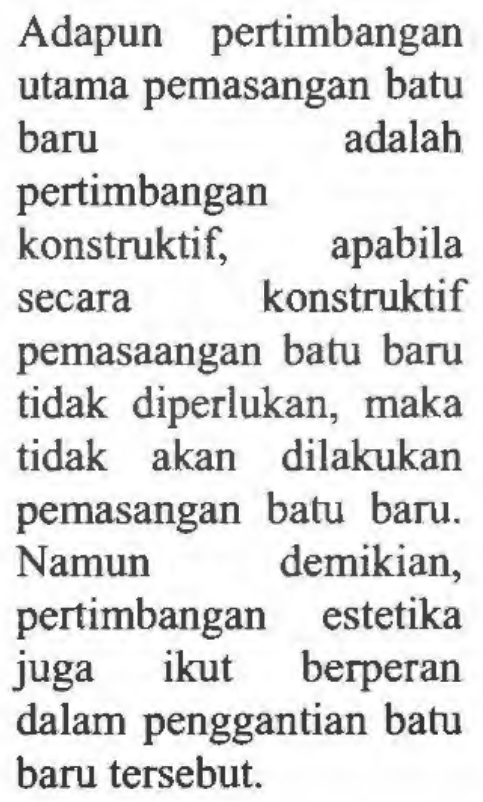

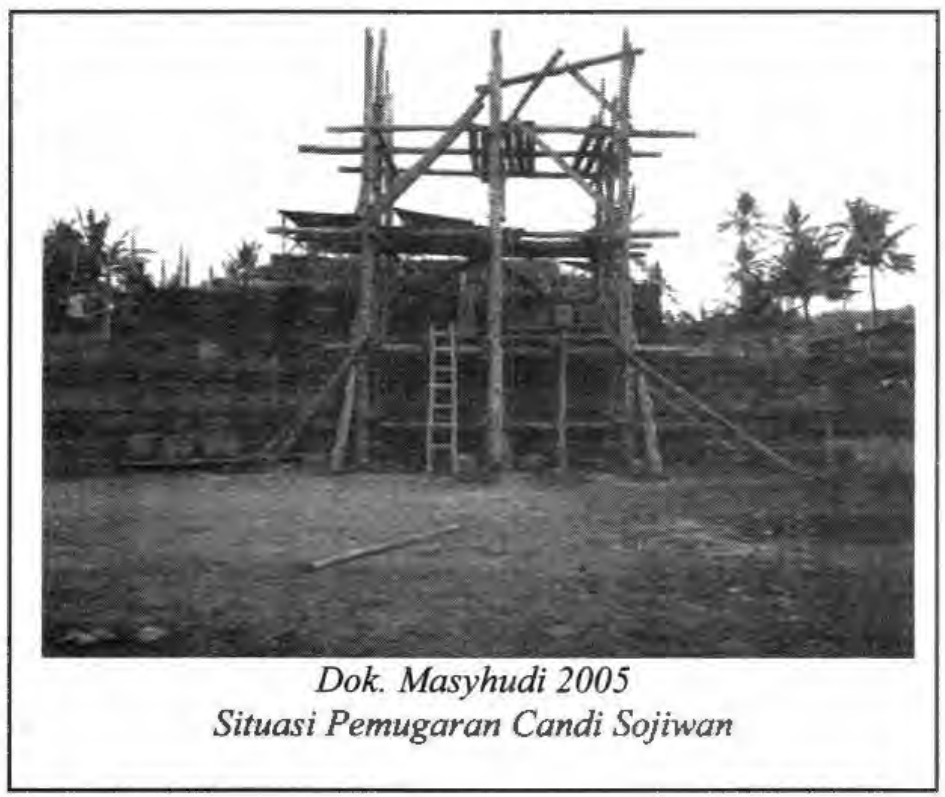

B. Konservasi.

Perencanaan dan pelaksanaan konservasi batu-batu candi terdiri dari registrasi batu, transportasi, pembersihan, perbaikan, pembuatan batu baru, pemasangan lapisan kedap air, threatment dan coating. Pekerjaan ini

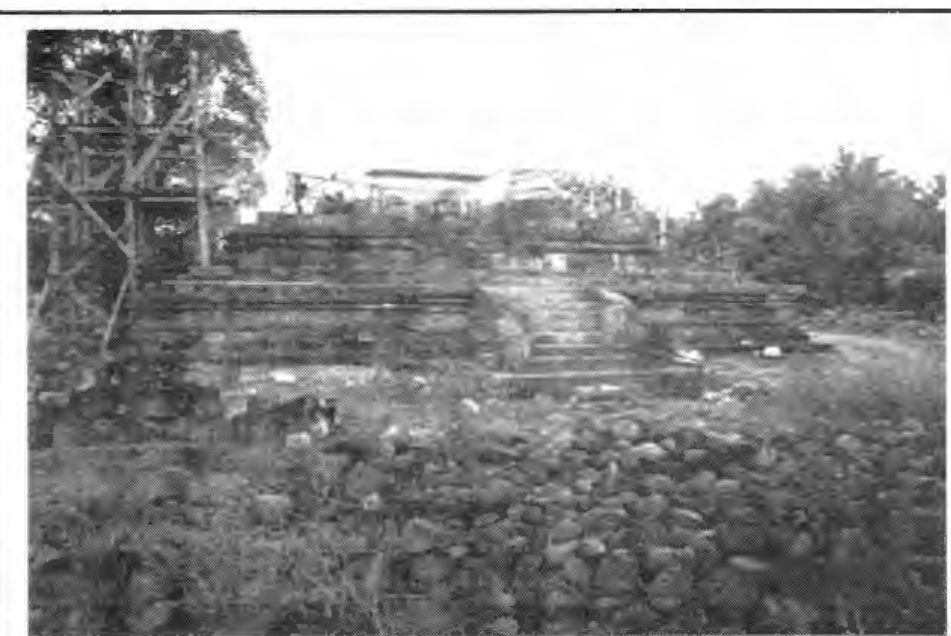

Dok. Masyhudi 2005

Situasi Pemugaran Candi Sojiwan dilakukan pada saat pembongkaran dan pemasangan kembali.

Registrasi batu dilakukan pada saat dilakukan pembongkaran sisa bangunan candi berlangsung. Sebelum batu-batu candi tersebut diturunkan dilakukan penomoran terlebih dahulu sesuai dengan posisi dalam bangunan. Hal ini dimaksudkan untuk memudahkan pengembalian batu-batu kulit ke posisinya semula. Dalam hal transportasi, untuk batu-batu Candi Sojiwan, hasil pembongkaran, hasil susunan percobaan untuk dikonservasi dan siap dipasang kembali ke monumen di angkut dengan peralatan angkut forklif. 
Kemudian untuk proses pembersihan terhadap batu candi dilakukan secara serius dan bertahap agar tidak terjadi kerusakaan terhadap batu-batu candi. Dalam hal perbaikan batu dilakukan beberapa cara, yaitu:

1. Bonding, cara penyambungnan batu yang pecah dengan bahan perekat.

2. Doweling, penyambungan batu yang patah dengan menambah perkuatan angkur menggunakan perekat dan dipasang di tengahtengah.

3. Kamuflase, penambalan batu-batu yang terkelupas.

Pemasangan lapisan kedap air dimaksudkan untuk mencegah air hujan melalui nat-nat batu. Sementara itu, treatment dilakukan pada batu kulit sebagai upaya agar batu-batu yang sudah dibersihkan atau batu kulit yang sudah dipasang tersebut tidak cepat ditumbuhi jasad organik atau menghambat tumbuhnya kembali jasad organik. Kemudian pada pekerjaan coating dilakukan melalui:

- Coating batu kulit dipasang kembali

- Coating angkur hak penguat teka batu

\section{Dokumentasi}

Dilakukan pendokumentasian selama pemasangan kembali batu-batu candi adalah untuk mengetahui serta membandingkan situasi bangunan candi sebelum pembongkaran dan setelah dilakukan pemasangan kembali batubatu candi. Teknis pemotretan dilakukan dengan mengambil dari arah kiri, dari arah kanan dan dari atas, dengan maksud memperoleh gambaran yang lebih jelas.

\section{Harapan dalam Pelestarian dan Pemanfaatan Sumberdaya Arkeologi}

Upaya pelestarian terhadap peninggalan sejarah dan purbakala adalah suatu upaya untuk menjaga kelestarian suatu obyek dengan segala potensi yang ada, sehingga dapat bermanfaat untuk kesejahteraan hidup manusia. Oleh karena itu upaya pelestarian harus diawali dengan menumbuhkan apresiasi masyarakat tentang pentingnya warisan budaya yang dapat dimanfaatkan untuk peningkatan jati diri dan peningkatan kesejahteraan hidup masyarakat, sehingga upaya pelestarian terhadap suatu sumberdaya budaya hendaknya dilaksanakan dengan mempertimbangkan asas manfaat, sedangkan dalam pemanfaatan benda cagar budaya harus selalu berwawasan pelestarian.

Sementara itu, Soekmono berpendapat bahwa, dalam pemugaran tidak harus menghasilkan utuhnya kembali bangunan kuna yang dipugar, artinya penambahan untuk melengkapi bagian yang kurang tidak perlu dilakukan, meskipun dalam gambaran rekonstruksi menunjukkan adanya kemungkinan dan 
meskipun dalam gambaran rekonstruksi menunjukkan adanya kemungkinan dan memberikan peluang. Kemudian dalam rangka pemanfaatan suatu situs, agar memperhatikan lingkungan. Dalam hal ini perlu mengikutsertakan masyarakat sekitar, terutama dalam hal pendidikan tentang pelestarian peninggalan purbakala, sehingga suatu situs cagar budaya yang memiliki potensi sebagai obyek wisata tidak hanya sekedar tempat rekreasi melainkan juga sebagai tempat untuk menambah ilmu dan memperluas wawasan (Soekmono, 2003 ).

Kelestarian Situs Candi Sojiwan perlu dijaga, karena situs tersebut merupakan salah satu aset budaya yang dimiliki oleh daerah. Kekhawatiran yang muncul pada bangunan candi ini adalah semakin lama semakin terancam keselamatannya yang dapat disebabkan oleh beberapa faktor antara lain:

1. Kerusakan yang disebabkan oleh faktor alam, misalnya gempa bumi, Banjir, dan letusan gunungapi.

2. Kerusakan oleh faktor kimia, seperti adanya pengaruh oksidasi.

3. Kerusakan yang disebabkan oleh faktor biologik, disebabkan oleh perlakukan benda-benda hidup, seperti tanaman, binatang, dan manusia.

Dalam pemanfaatan sumberdaya arkeologi haruslah berorientasi pada pelestarian. Hal ini disebabkan oleh jumlah sumberdaya arkeologi yang terbatas, tak terbaharui (non renewable), tak dapat dipindahkan (non movable), serta mudah rapuh. Oleh karena itu dalam upaya pemanfaatan terhadap kawasan budaya sebagaimana tersebut di atas hendaknya dimanfaatkan dengan hati-hati. Kemudian dalam hal pengembangan terhadap aset budaya harus pula melihat nilai dari berbagai kepentingan, sehingga berbagai konflik kepentingan yang ada dapat ditekan secara maksimal agar tidak ada upaya untuk saling mengalahkan, tetapi saling menguntungkan.

\section{Kesimpulan}

Pemugaran Candi Sojiwan, sampai saat ini masih dalam tahap awal pelaksanaan, yakni sampai pada tahap pemasangan pondasi atau bagian kaki candi. Pada beberapa bagian lain termasuk pemasangan lantai selasar, pemasangan tubuh dan atap candi, dan pemasangan tangga candi belum dilakukan.

Meskipun demikian, pemugaran terhadap Candi Sojiwan ini akan berlangsung sesuai dengan rencana kegiatan, sebagaimana telah dipersiapkan pada tahap persiapan pemugaran (pra pemugaram). Karena kegiatan pelaksanaan pemugaran masih terus akan berlanjut, maka perlu adanya suatu jalinan kerjasana dengan beberapa instansi atau lembaga terkait terutama dalam hal kebutuhan sumberdaya manusia yang memiliki keahlian dalam beberapa bidang 
tertentu, sehingga kelancaran pelaksanaan pemugaran tersebut akan menunjukkan hasil yang sesuai dengan harapan semua pihak

\section{DAFTAR PUSTAKA}

Acharya, Prasanna Kumar. 1993. Architecture of Manasara. Oxford University Press, London.

Anonim. 2003. Laporan Bulanan Pemugaran Candi Sojiwan. Proyek Pemanfaatan Peninggalan Sejarah.

Blom, J.R. Van. 1935. Tjandi Sadjiwan. H.R. Stenfert Kroese's Uitg. Mij, Leiden.

Boechari. 1978. Bahan Kajian Arkeologi untuk Pengajaran Sejarah. Majalah Arkeologi Th. II, No. 1.

Kempers, A.J. Bernet. 1959. Ancient Indonesian Art. Harvard University Press, Amsterdam.

Kramrisch, Stella. 1946. The Hindu Temple. University of Calcutta, Calcutta.

Mundardjito. 1993. Pertimbangan Ekologi dalam Penempatan Situs Masa HinduBuda di Daerah Yogyakarta: Kajian Arkeologi Ruang Skala Makro. Disertasi. Universitas Indonesia, Jakarta.

Soekmono. 1977. Candi Fingsi dan Pengertiannya. IKIP Semarang Press, Semarang.

1993. Ratu Boko Quo Vadis. Dalam Pertemuan Teknis dalam Rangka

Evaluasi Program Pemugaran Situs Ratu Boko, Yogyakarta.

Stutterheim, W.F. 1937. He Zinrijke Waterwerk van Djalatoenda, TBG LXVII: 173216. 